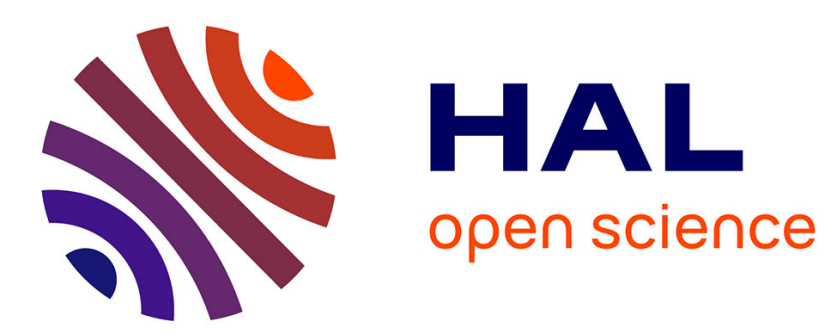

\title{
The location of Multinational Firms in the European Urban System
}

Céline Rozenblat, Denise Pumain

\section{To cite this version:}

Céline Rozenblat, Denise Pumain. The location of Multinational Firms in the European Urban System. Urban Studies, 1993, 30 (10), pp.1691-1709. hal-01524115

\section{HAL Id: hal-01524115 \\ https://hal.science/hal-01524115}

Submitted on 17 May 2017

HAL is a multi-disciplinary open access archive for the deposit and dissemination of scientific research documents, whether they are published or not. The documents may come from teaching and research institutions in France or abroad, or from public or private research centers.
L'archive ouverte pluridisciplinaire HAL, est destinée au dépôt et à la diffusion de documents scientifiques de niveau recherche, publiés ou non, émanant des établissements d'enseignement et de recherche français ou étrangers, des laboratoires publics ou privés. 


\section{The Location of Multinational Firms in the European Urban System}

Céline Rozenblat and Denise Pumain

[Paper first received, January 1992; in final form, December 1992]

Summary. The progress of political and economic integration among European countries is inducing the progressive emergence of a European urban system. National urban systems are restructuring and adapting themselves to this new international and economic context. The location of the largest multinational firms is taken as revealing a major step in the process of the integration of European cities into supra-national networks. A survey of the location of 3000 establishments belonging to the $\mathbf{3 0 0}$ largest European firms provides interesting results about the factors making European cities attractive for such activities. It may be inferred from these results that they confirm a new trend called 'metropolisation', which is reinforcing the top of the national urban hierarchies, as demonstrated in other studies.

\section{Introduction}

With growing economic integration in the framework of the European Economic Community and because of the multiplication of connections between all European countries, the urban systems are restructuring. For a long time they have been evolving under constraints which were mainly acting inside the national boundaries, but nowadays cities are becoming more and more interdependent. A pean urban system is emerging. Questions about its future configuration are many: which cities have the best situations in the inter-urban competition for attracting resources, activities and population? Will the largest cities take benefit from this restructuring at the expense of small and medium-sized ones? Which geographical situations and policy options will be more in favour of urban development?

Several processes are to be considere

when trying to make predictions about the future of the European urban system, in relation with the expanding internationalisation of exchanges. One is the development of more efficient communication systems, including high-speed trains, international airports and specialised networks fo telecommunications. Many studies have already shown that such processes have contributed at first to reinforce the hierarchy in the European urban system, since largest cities with the widest markets benefitted from the initial advantage of locaion for this type of infrastructure (Auphan, 1991; Bieber, 1990; Cauvin et al., 1989; Cattan, 1990).

Another process of importance for connecting and restructuring the European urban system is the growing internationalisation of firms and the organisations of economic net- 
classical theory of hierarchical innovation diffusion for such a type of entrepreneurial innovations, one would also expect a reinforcement of existing urban hierarchies through that process. However, detailed studies of the evolution of the spatial organisations of firms have shown that the hierarchical pattern of diffusion was not always the most probable and that cities could also be connected according to other types of networks (Pred, 1977).

There are several possible ways of testing such an hypothesis. Surveys have been conducted among firms in order to know their locational preferences (IFO, 1990; EEC 1990). Other surveys have investigated the urban factors which are correlated with the degree of internationalisation of urban activities by sending questionnaires to the cities (MOCI, 1989; Bonneville et al., 1991; Rozenblat, 1991). A third method will be presented here, which consists in revealing the location factors through a study of the actual presence of economic branches of foreign origin within European cities.

The existence of subsidiary companies of foreign firms in a city, and the fact of a city hosting firms which have subsidiary companies in foreign countries, are considered as two different measures of the level of integration of a city to supra-national networks, via the internationalisation of economic activities. Those various integration level are then correlated to indicators of urban size and situations.

In order to analyse the location of foreig firms within the urban system, we made survey of a sample of the 300 largest European firms, providing information on about 3000 of their implantations located abroad throughout Europe. The collection of comparable cross-national information at relevant urban level is still a difficult exercise for Europe as a whole.

2. Problems of European-wide Dat Collection and Comparison

Despite the existence of a specialised institution, EUROSTAT, which provides data sets at various regional levels for all EEC countries, there is no official source of comparable data at the urban level. The definitions of what can be considered as an urban entity vary from one country to anthe concept is restricted to the 'local unit' or 'municiplity', ot including the posible sububa exten ins possible suburban extentions over the neighbouring administrative units. Several countries have defined urban agglomerations (or 'urban areas') according to morphological criteria, only a few use concepts analogous to SMSA (Pumain et al., 1990).

The pioneer work of Hall (Hall and Hay, 1980) tried to solve this problem by designing functional urban regions for many European countries, upon criteria which were adapted from the ones being used for US SMSAs. However, the absence of statistics about commuting in several countries renders very difficult an homogeneous application of such criteria. That is why the database which is used here considers cities in the geographical framework of 'urban agglomerations': the main criteria of the definition is the continuity of the built-up area, and the delimitation includes all the administrative local units the majority of whose population lives within the continuous built-up area. The definition is homogeneous for all European countries. This database was prepared in order to be compatible with the world-wide database GEOPOLIS (Moriconi, 1991) using all available statistical, cartographic and airphotograph material, in order to provide the most comparable delimitations. Population data are regularly updated for each decade between 1950 and 1990 .

The concept of urban agglomeration would not be broad enough to study the more recent forms of urban extensions in low-density areas. However, due to the urbanisation pattern of most European cities, it does capture the essential part of their population and economic weights, which is what is needed for our study, and it does it in the most rigorous way possible for a European-wide comparison. Data about population and economic activity have been collected and

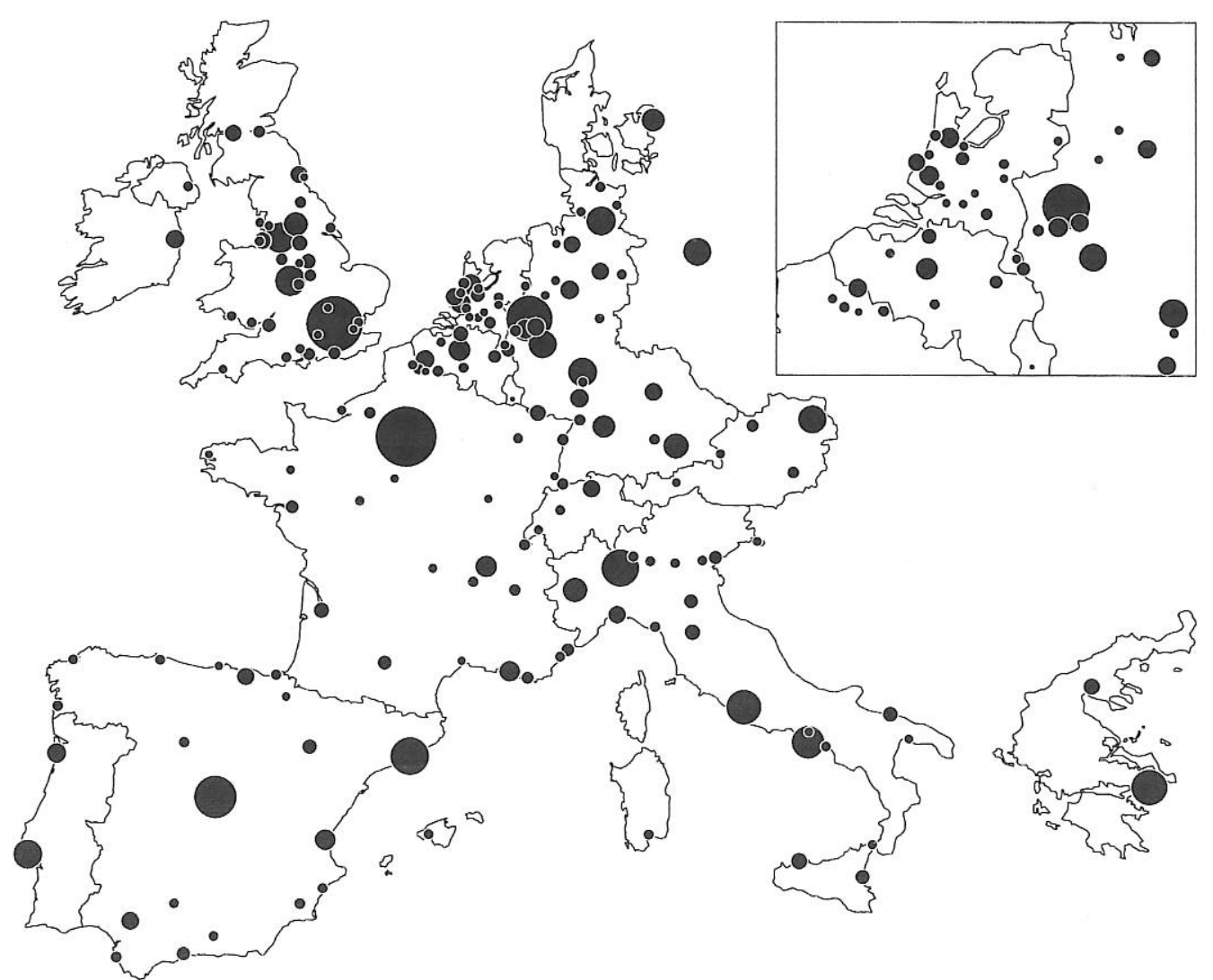

POPULATION 1981

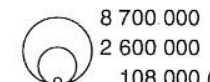

Figure 1. The West European urban system of cities having more than 200000 inhabitants (1981) Source: Equipe P.A.R.I.S. (1990).

aggregated in this spatial framework by Cattan and Rozenblat (1991) for the 169 urban agglomerations with 200000 inhabitants and more, in the $12 \mathrm{EEC}$ countries plus Austria and Switzerland (Figure 1).

In order to locate foreign firms in those large agglomerations, a questionnaire was sent to the 300 largest European enterprises quoted by Duns and Bradstreet (1990) asking for a list of their for a lis 0 foreign countries, indicating their location, size and activity. Ninety-four firms answered, without any noticeable bias in size, country or type of industry (Table 1). They provided a sample of 2798 foreign branches having a European location.
It was impossible from this source to know he exact date when the firms were first settled in their actual location. Thus, it is not the process of internationalisation which can be studied, but only the state of diffusion that it has now reached throughout the European urban system.

\section{The Location of Headquarters}

The distribution of the headquarters of the 300 largest European firms in 1988 provides an image of the actual state of concentration of the economic decision power among European cities (Figures 2 and 3). Despite the rather small size of the sample, the results 
Table 1. The 94 firms of the survey compared with the sample of the 300 first European firms (1988

\begin{tabular}{|c|c|c|c|c|c|}
\hline & \multicolumn{2}{|c|}{ First 300 European firms } & \multicolumn{2}{|c|}{ Firms of the survey (94) } & \multirow{2}{*}{$\begin{array}{l}\text { Difference } \\
\text { Percentage }\end{array}$} \\
\hline & Number & Percentage & Number & Percentage & \\
\hline \multicolumn{6}{|l|}{$\begin{array}{l}\text { Country of location of } \\
\text { the headquarters }\end{array}$} \\
\hline Austria & 4 & 1.3 & 2 & 2.1 & 0.8 \\
\hline Belgium & 8 & 2.7 & 3 & 3.2 & 0.5 \\
\hline Denmark & 0 & 0.0 & 0 & 0.0 & 0.0 \\
\hline Spain & 10 & 3.3 & 1 & 1.1 & -2.3 \\
\hline France & 74 & 24.7 & 20 & 21.3 & -3.4 \\
\hline Great Britain & 96 & 32.0 & 29 & 30.9 & -1.1 \\
\hline Greece & 0 & 0.0 & 0 & 0.0 & 0.0 \\
\hline Ireland & 0 & 0.0 & 0 & 0.0 & 0.0 \\
\hline $\begin{array}{l}\text { Italy } \\
\text { In }\end{array}$ & 21 & 7.0 & 4 & 4.3 & -2.7 \\
\hline Luxemburg & 0 & 0.0 & 0 & 0.0 & 0.0 \\
\hline Netherlands & 0 & 0.0 & 0 & 0.0 & 0.0 \\
\hline \multicolumn{6}{|l|}{$\begin{array}{l}\text { Netherlands } \\
\text { Federal Republic of }\end{array}$} \\
\hline Germany & 60 & 20.0 & 21 & 22.3 & $\begin{array}{l}2.3 \\
3.4\end{array}$ \\
\hline Switzerland & 9 & 3.0 & 6 & 6.4 & \\
\hline \multicolumn{6}{|c|}{ Main activity of the firms } \\
\hline $\begin{array}{l}\text { Agriculture } \\
\text { Food industry }\end{array}$ & 0 & 0.0 & $\begin{array}{l}0 \\
8\end{array}$ & $\begin{array}{l}0.0 \\
8.5\end{array}$ & $\begin{array}{l}0.0 \\
0.8\end{array}$ \\
\hline $\begin{array}{l}\text { Food industry } \\
\text { Energy and chemistry }\end{array}$ & 23 & $\begin{array}{r}7.7 \\
167\end{array}$ & $\begin{array}{r}8 \\
11\end{array}$ & $\begin{array}{r}8.5 \\
11.7\end{array}$ & $\begin{array}{r}0.8 \\
-5.0\end{array}$ \\
\hline \multirow{2}{*}{\multicolumn{6}{|c|}{$\begin{array}{l}\text { Energy and chemistry } \\
\text { Basic products, electrical } \\
\text { and electronic }\end{array}$}} \\
\hline & & 23.7 & 26 & 27.7 & 4.0 \\
\hline Transport equipment & 33 & 11.0 & 14 & 14.9 & 3.9 \\
\hline Other manufacturing & 4 & 1.3 & 0 & 0.0 & -1.3 \\
\hline Building & 7 & 2.3 & 2 & 2.1 & -0.2 \\
\hline Trade & 51 & 17.0 & 15 & 16.0 & -1.0 \\
\hline $\begin{array}{l}\text { Transport, } \\
\text { communications }\end{array}$ & 15 & 5.0 & 5 & 5.3 & 0.3 \\
\hline $\begin{array}{l}\text { Services (except } \\
\text { finances) }\end{array}$ & 11 & 3.7 & 4 & 4.3 & 0.6 \\
\hline $\begin{array}{l}\text { finances) } \\
\text { Financial services }\end{array}$ & 33 & 11.0 & 9 & 9.6 & -1.4 \\
\hline Administration & 2 & 0.7 & 0 & 0.0 & -0.7 \\
\hline
\end{tabular}

Source: Duns \& Bradstreet (1980).

are similar when other sources are used, like when the importance of the firms is measured Eurobusiness, or the 500 largest firms published by the magazine Fortune. They are lished by the magazine Fortune. They are mapping the 700 largest European firms mapping the 700 .
(Reynard, 1977).

The spatial distribution of the headquarters is highly concentrated, with very large quantities of firms in London (83 headquarters, 28 per cent of the European total) and Paris (67, 22 per cent). These two capitals concentrate by their turnove

Other clusters of headquarters of less importance are located mainly in several cities of north-west Europe (Brussels, Amsterdam, Essen, Düsseldorf, Frankfurt, Hamburg, München) and only very small numbers are to be found in cities of southern Europe, with the exceptions of Madrid, Roma, Milano and Torino.

In Europe as a whole, there is a high together one-half of the European headquar- concentration of headquarters in the largest ters, and the proportion is roughly the same cities. Only a few are located in cities with

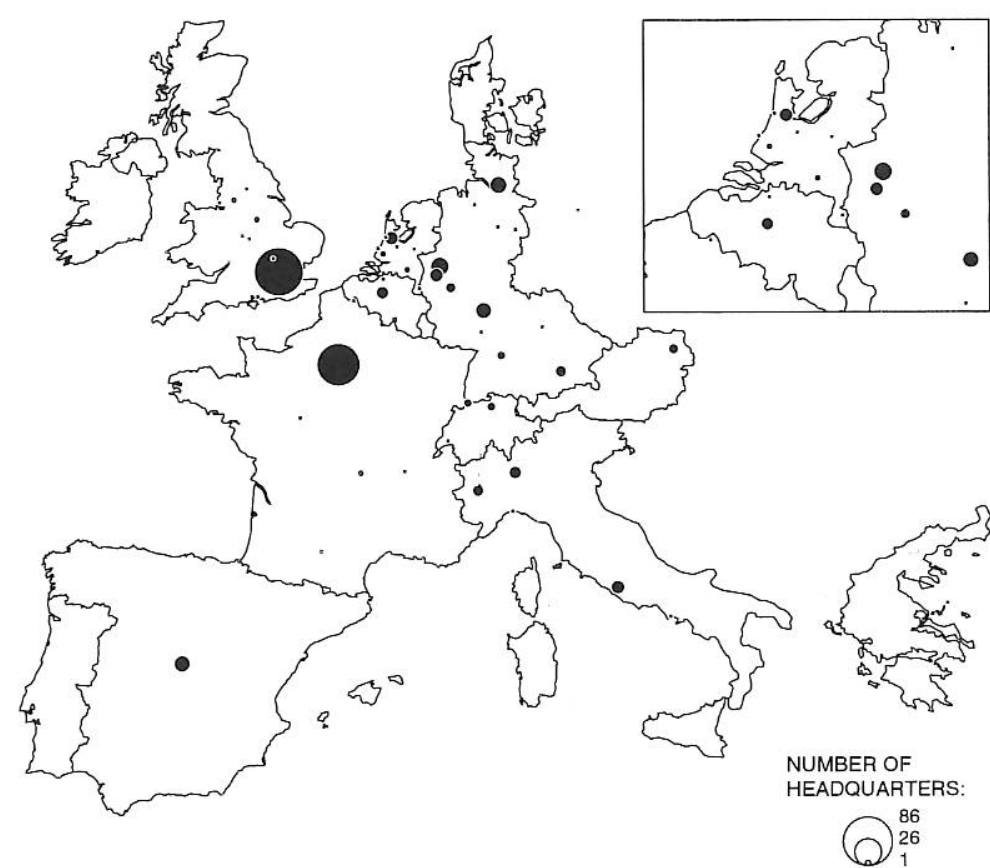

Figure 2. Headquarters of the first 300 European firms, 1988. Source: Duns \& Bradstreet (1990).

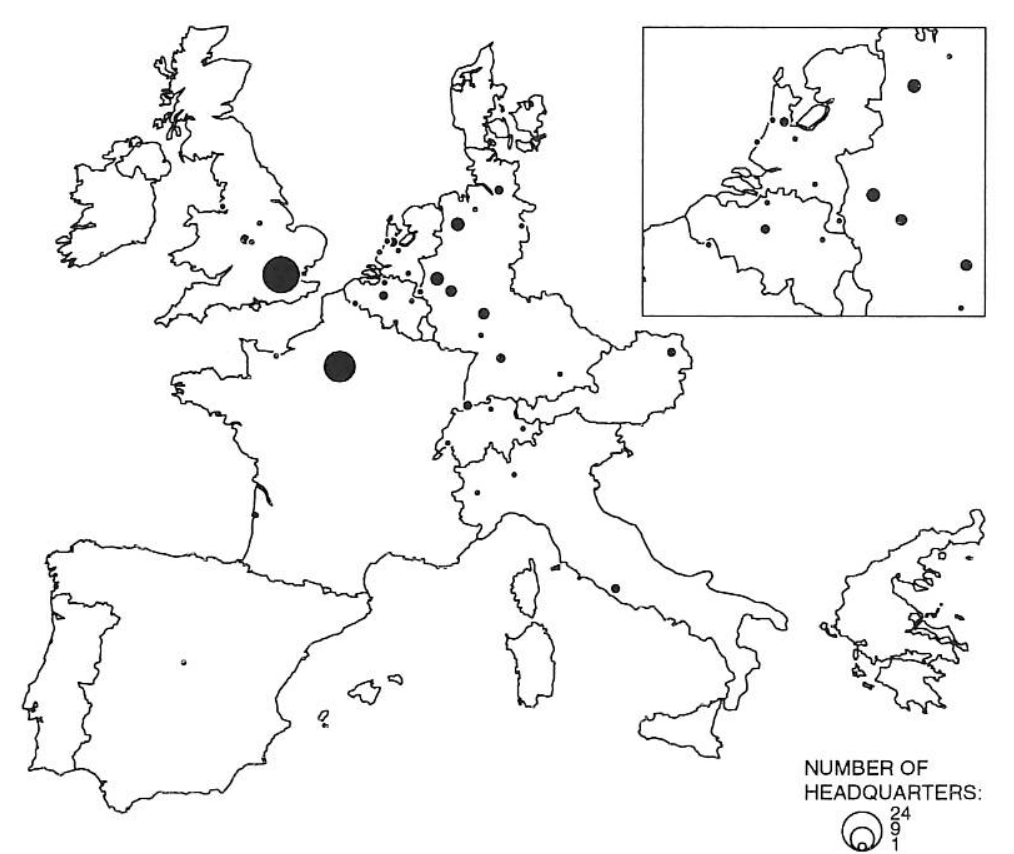

Figure 3. Headquarters of the 94 surveyed firms. 
less than 200000 inhabitants: Wolfsburg, Greece and Spain, and in Luxemburg of Salzgitter and largest diffusion in the counSalzgitter and Ingolstadt in Gernany

in France, Milton Keynes in England, Glarus in Switzerland, Ravenna in Italy, Genk in in Switzerland, France and Denmark.

Belgium and Groningen in the Netherlands. Glarus excepted, all these cities have over 100000 inhabitants.

\section{Location of Foreign Subsidiaries}

The number of foreign subsidiaries reveal the importance of foreign investment in city. It also refers to a part of the economy of a city which is necessarily connected to external networks. The spatial distribution of foreign subsidiaries in European countries reflects the actual state of the diffusion of the reflects the actual state of the diffusion of the firms. process of internationalisation of the fir firm are located in agglomerations of over 200000 inhabitants, 17 per cent in smaller towns and only 5 per cent in the countryside (Table 2 and Figures 4 and 5). Their location (Table 2 and Figures 4 and 5). Their location is mainly limited to the top of the urban hierarchy, and this fact possibly results from a filtering-down process in the internationalisation of the urban economies. The distribution of the branches is however not so strongly concentrated in a few leading cities as is the distribution of headquarters. This is a first and well-known indication about the locational preferences of the economic firms, which maintain their main decision centres close to the places where the political and financial powers are also located.

The highest concentration of foreign subsidiaries is in Paris (193) followed by Milano (116), Brussels (115), Barcelona (114) and London (110). For those countries obviously, one or two main cities have a role of bridgehead for foreign investments. By contrast, in the case of Germany, which is the country receiving the largest number of foreign firms, the implantations are shared by six main citce : Essen, Diisseldof, Köln-Bonn, Frankfurt, ies. Essen, Dusseldorf, Köln-Born, Frant, München and Hamburg, with about 40 foreign firms each. Those cities are at the same leve as Manchester, Lyon or Rome, which have the second rank in their respective countries. Metropolitan locations are more frequent in
The diffusion level may vary according to the sector of activities. There is a slight trend for a less concentrated location of manufacturing than for services: 76 per cent of manufacturing subsidiaries against 84 per cent of services subsidianies have chosen the large cities, whereas 65 per cent and 25 per cent respectively are to be found in countryside locations. A few economic activities tend to concentrate more in the largest cities: civil engineering, financial services and also, at a lower level, transport and telecommunications, local services and energy. On the cations, local services for final demand more other hand, industries for final demand more often choose the small towns and of course they are more likely to be found in the

More contrasted preferences according to he size of cities appear if, instead of considring the sector of activities, one observes ing furms inside the main , rm, as functions of decision, research, quarters and financial services are mainly found in large metropolises, whereas production or multifunctional establishments are more decentralised and widely diffused within the lower part of the urban hierarchy. Neither is the location of the oriented firms very centralised.

The metropolisation process due to the internationalisation of firms is highly selective, then, according to the desired proximity of the main decision centres. It follows the seneral rule of the 'new spatial division of 'lab ' a quoted by Aydalot (1985): decilaber' as quoct by Ayds ot (1985) sion or financial activities on the one hand are close to the centres of economic and political power, whereas production- and research-oriented activities on the other hand have more diverse types of location.

The propensity to diffuse may also vary according to the country of origin of the firms and reflect then the duration of the inernationalisation process: old practitioners of exporting activities like Belgian, Swiss cent of services subsidiaries have chosen the countryside (Table 3 ). production or distibution (Table 4). Head

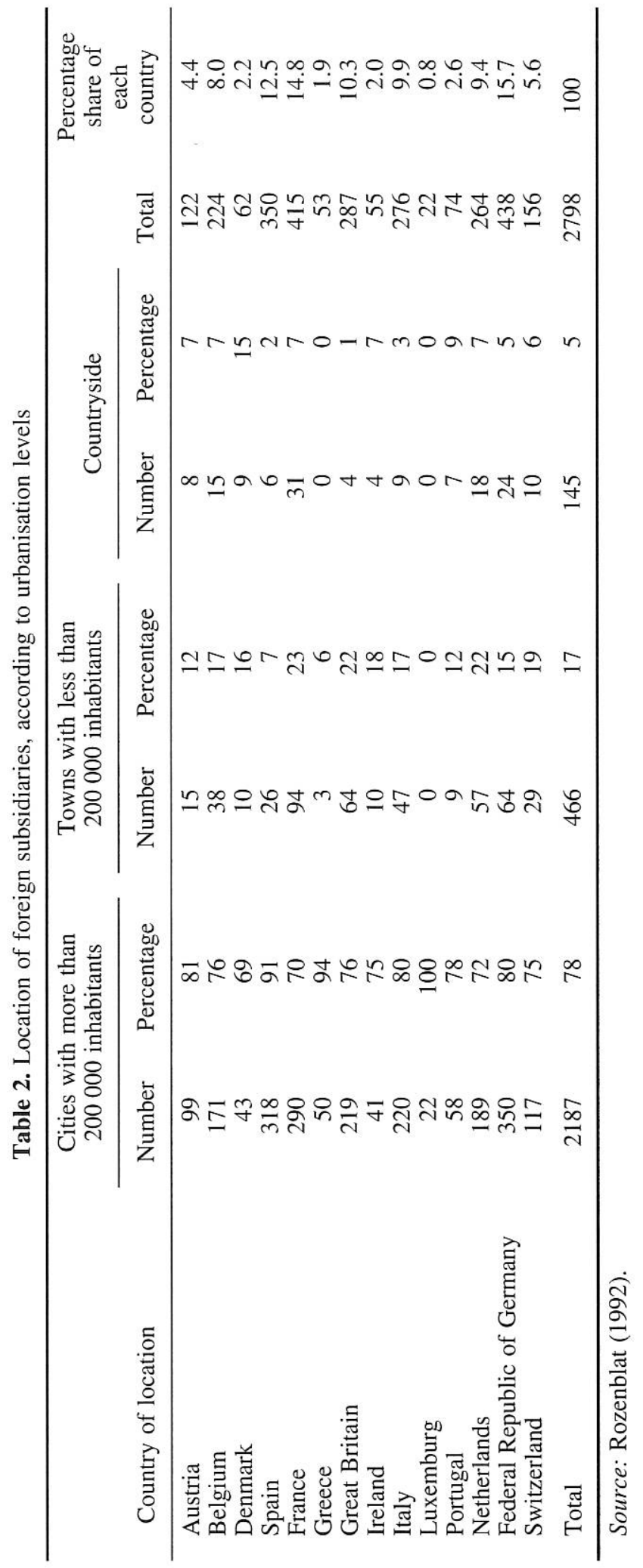



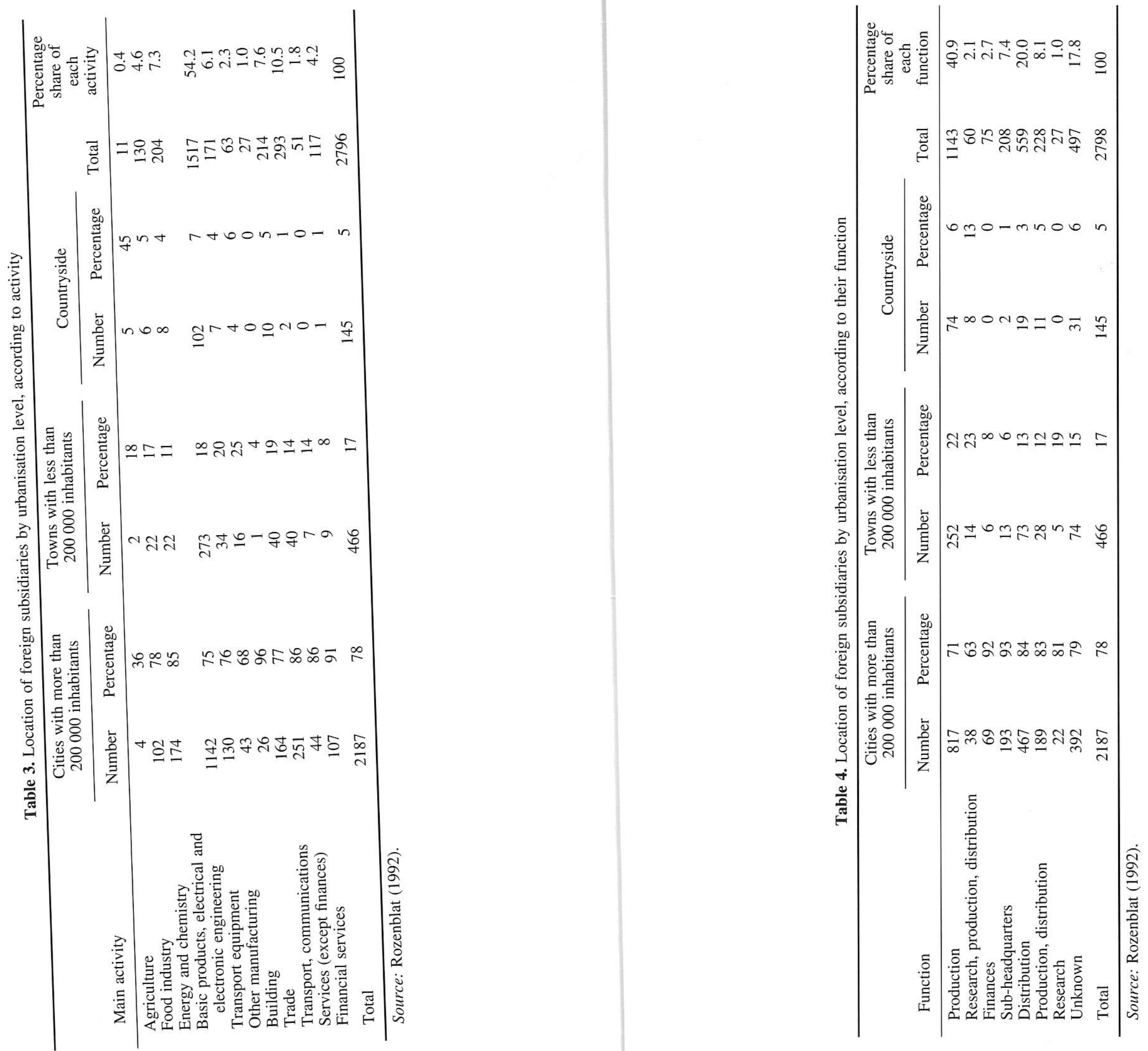


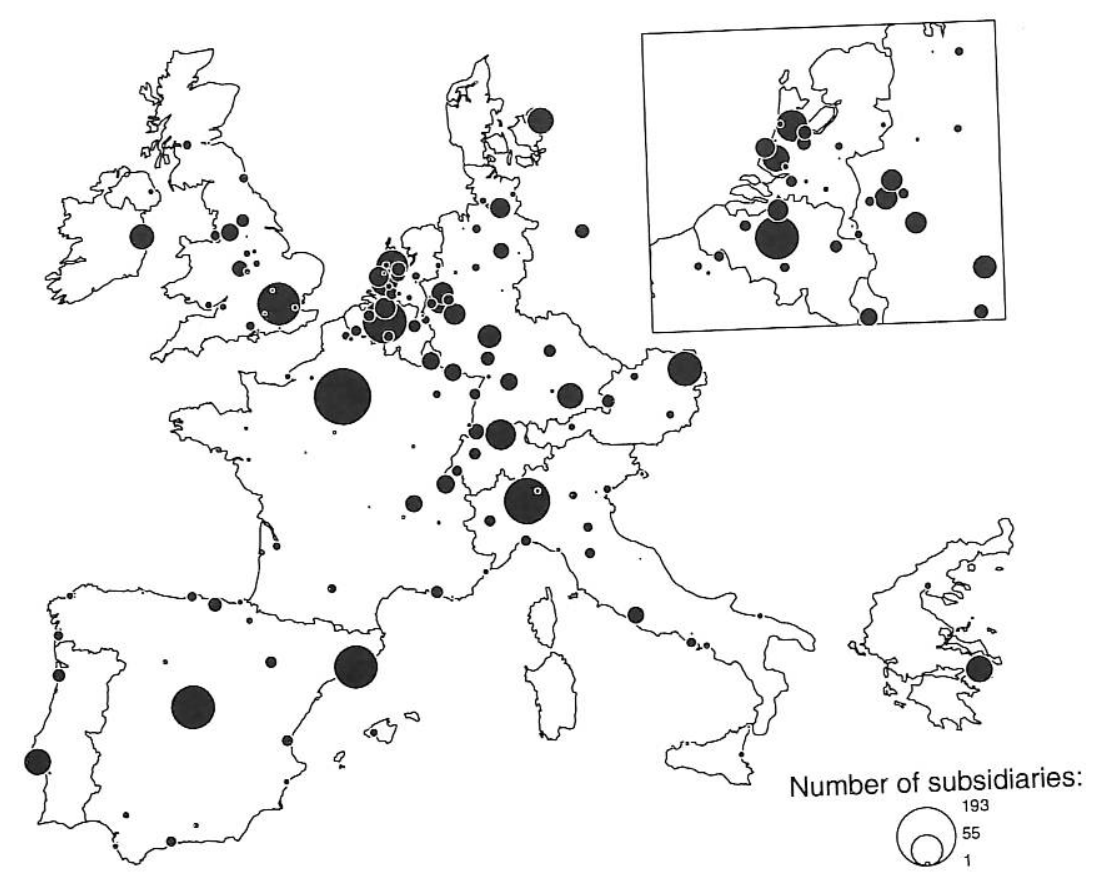

Figure 4. Location of foreign subsidiaries within cities having more than 200000 inhabitants.

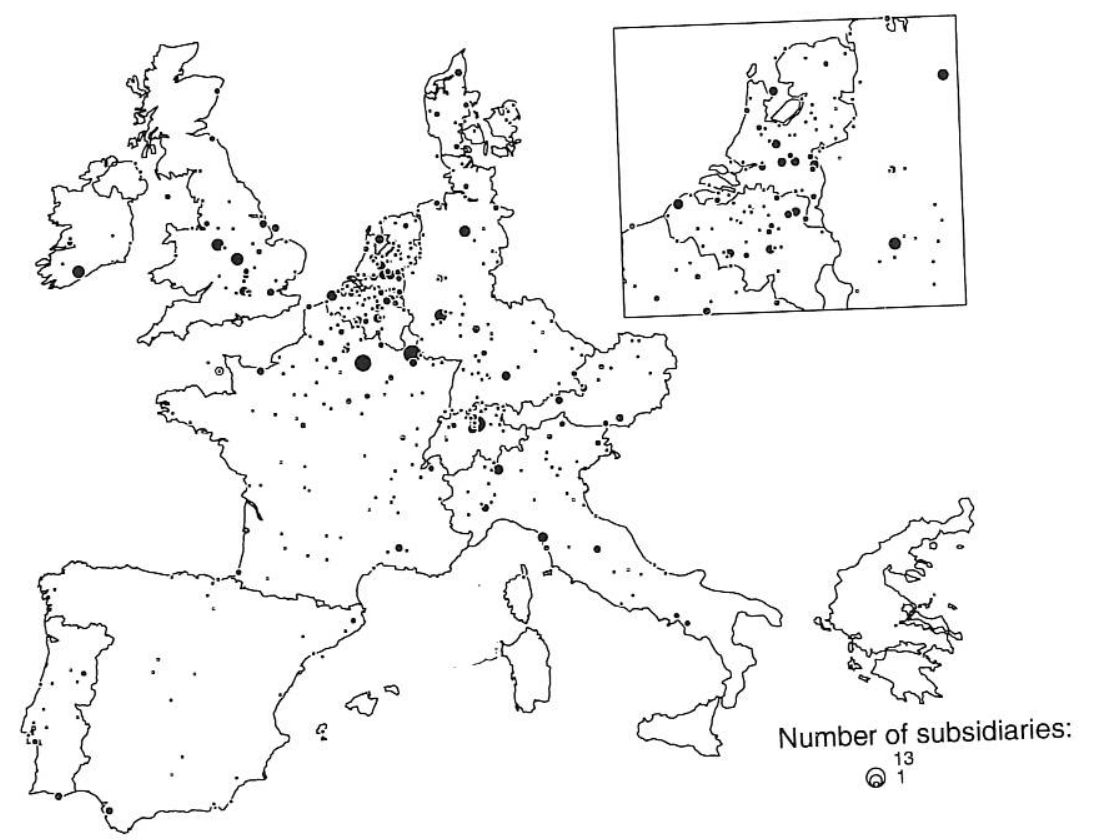

Figure 5. Location of foreign subsidiaries outside of cities having more than 200000 inhabitants. and Dutch firms choose countryside implantations much more often than Spanish ones which started their internationalisation later.

\section{Interdependences and Dominations}

The location of foreign firms also reveals a selection of the city of destination by economic investment according to their country of origin: French investments choose more often Madrid, Geneva, Saarbrücken and Stuttgart; British investments are more directed towards Dublin, Köln-Bonn and Hamburg; whereas German funds prefer Antwerpen, Rotterdam and The Hague. Belgian firms invest more in Luxemburg, Essen and Hannover; and Austrian firms choose almost exclusively Zurich and München.

From our survey it was possible to identify the city in which were located the subsidiaries of firms having a headquarters located within one of the European cities in our sample. We analysed the squared matrix where the headquarters city is considered as the origin, and the city receiving a branch is the destination. The total number of such links is considered as a 'flow' between two cities. This number reveals the intensity of economic control through foreign branches from one city to another. Two-way 'exchanges' of foreign branches are used to measure the intensity of flows of internationalisation between cities on the one hand, whereas the more or less symmetrical character of those relations define links of 'domination' between cities on the other hand

The ten largest relations concern five cities only. London controls 49 subsidiaries in Paris; Paris has 48 in Madrid, 37 in Brussels (which has 22 in Paris), 34 in Milano and 32 in London; whereas London has only 24 in Milano, 23 in Brussels and 21 in Madrid (Figure 6). In such a small system of cities receiving and sending more than 20 links, London has more control on Paris than the reverse, but the number of cities controlled by Paris is larger. Paris also receives more branches from those cities than London does. Another system can be seen around Vienna, which has 19 subsidiaries in Munich and 15 in Zurich. Wien also has links with the other sub-system since it controls 13 branches in Paris and 7 in London, and receives 13 from Paris and 12 from London.

So the geographical situation of cities seems as important as their size in explaining the intensity of relationships through the exchange of subsidiaries. However, an adjustment by a simple gravity model explains only 48 per cent of the inequalities of the links of foreign branch control.

The imbalances in the numbers of firms controlled between each couple of cities can be measured by an index which divides the net exchange (number of 'exported' firms minus the number of 'imported' ones) by the sum of all imported and exported (Figure 6). After this index, there is no relationship of 'dominance' between London, Paris and Brussels. But these three cities dominate strongly Madrid and Milano. On the whote western German cities dominate the cities of the Benelux, whereas the southern German cities are controlled by Wien, with many connections depending also from Paris, London and Brussels.

Of course the interpretation of asymmetrical relationships in terms of dominance and dependence has to be cautious. It puts forward the city where headquarters are located and which has divided the economic risks into many foreign investments, but it does not mean necessarily that the 'depending' cities which receive more foreign firms than they invest are in a threatening situation. They may also gain advantages from a better integration to the European urban system. Moreover, the exchanges of foreign subsidiaries are also difficult to interpret since all the links of dependence between cities are not direct. For instance, the spatial organigrams of three firms represented in Figure 7 show that in some cases, a foreign branch may itself control other subsidiaries in cities, either in the same country or in others. On the whole, 8 per cent of the total number of foreign subsidiaries are controlled in such an indirect way. It is then possible to identify 'intermediate cities', where such controlledcontrolling foreign firms are located. 

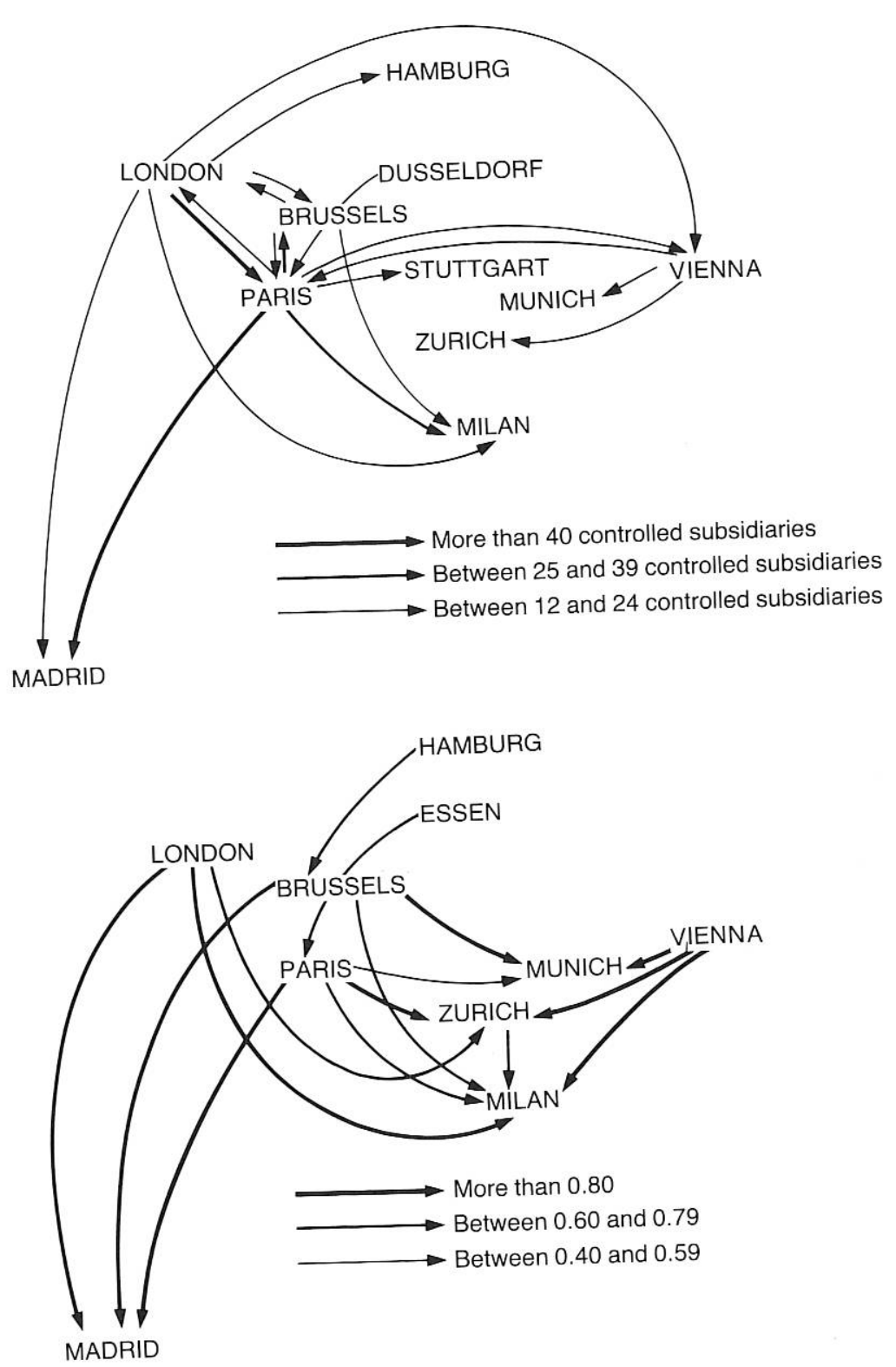

Figure 6. Interdependence and domination links between cities by control of subsidiaries:

These intermediate cities are of three are large cities (like London, Paris, Milan, These intern 'bridgehead', most of which Vienna, Barcelona, Stuttgart, Brussels and

\section{A. GRAND METROPOLITAN}

(only German part:

Pillsbury GMBH

and French part:

Pistral)

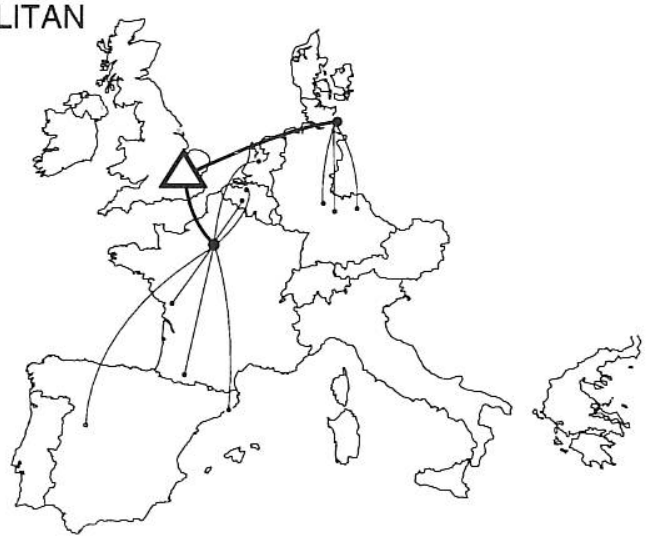

B. VEBA

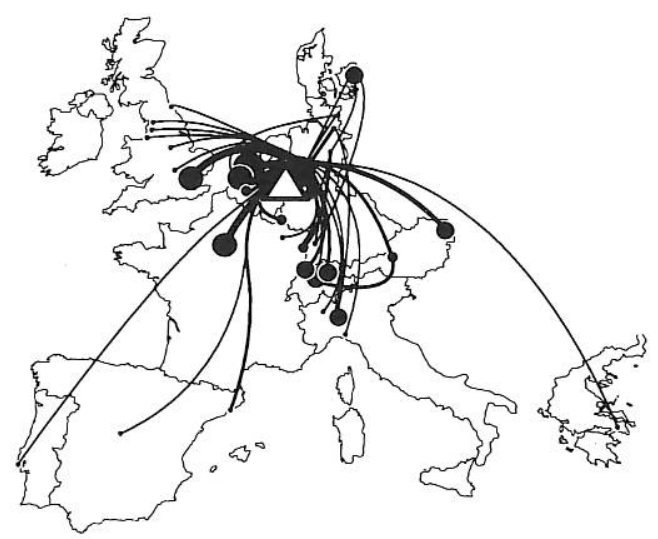

C. DAIMLER-BENZ

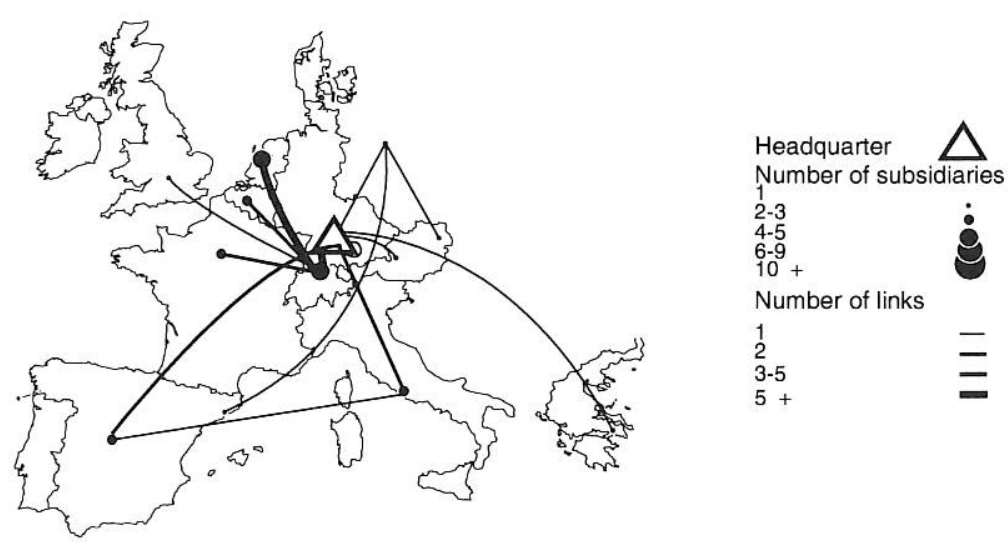

Figure 7. Direct and indirect control of foreign subsidiaries: examples of the spatial organisation of three firms.

Amsterdam), through which firms invest in out in the same way the foreign investment foreign countries. These cities do not spread on their national territory: for instance in 
Barcelona, all the indirectly controlled differences in the rate of penetration by for barcela eign investments from one state to the other. branches are located inside the city itself, expected that the accessibilwhereas Madrid redistributes more in the rest of Spain. Half of the branches indirectly ity of cities wir capacity to develop internacontrolled by London remain in that city, system, and thir capacity to deve their ability whereas Milan, Paris, Vienna and Amster- tional relationships, will inciare dam send them in a larger proportion towards to receive foreign subsidiaries. The functional specialisation of cities may add to their other cities in their coun- attractivity for firms of the same type. It The second type of intermediate cities 'ex- atrould also be suggested that a high demoport' abroad branches for firms whose could also be suther reflects or attracts headquarters are located in their own coun- graphic growth try. Cities of Austria, the UK and Germany foreign investonts. are such relays for firms located in other location factor, a cities. A third type of city owns subsidiaries made for French cities (MOCl, 1989, Rozenwhich abroad but which blat, 1991). The relevant explanatory which are contor variables were of two types: accessibility for in turn control branches out ide: the example of such 'turntables' is undoubtedly international relationships, and casitable Amsterdam, possibly due to taxation advantages.

The conclusion of this rapid investigation could be that the links which connect European cities through the internationalisation of their firms are already very complex and do not allow the derivation of a simple pattern of economic control within the urban system, but on the contrary exemplify a rather large complexity of interactions among European cities. If an hierarchy exists between cities, it is tied to the mass effect of the number of internationa links rather than to a large asymmetry of these links.

6. The Location Factors of Foreign Firm The preferences of firms in terms of location for their foreign implantations can be revealed by the characteristics of the cities that they choose more often. It may be expected the chrosion process, the size of the cities is important. A simple the size of the cities is important. A simple main location factor of foreign firms in Europea cities is their size. Size explains 65 per cen of the variations in both numbers of headof the variations in boriance quarters and subsidiaries. After a va 92 per analysis, the explanation level rises to 92 per cent when the size of cities is combined with their location within the different European countries, since there are still rather strong facilities. ean cities: accessibility was measured by n international population potential (countonly popstional boundaries); attractivity for international reationships was measured by ther airport raffic and by the number of internationa congresses hosted by the city; high-level interis measured by the number and capacity of four-star hotels; functional specialisation wa approached, due to the lack of comparable sources, by the share of labour force in tertiary activities; demographic growth was computed within comparable agglomeration comput wor four periods using the ramowork for four periods using the GEOPOLIS database (Moriconi, 1991). Most of these variables can be seen as conse-
quences as well as factors of the internationalisation

A correlation matrix was computed (Table 5). It shows that only variables reflecting . ity are linked to the number of foreign firms. ity are linked to thiables, this relationship is mainly an effect of size, since the correlation (the number of firms per inhabitant.) A multiple regression model selected four independent variables explaining 76 per cent of the variance in the number of foreign units within European cit-
Similar variables were collected for Eurocity; high-level




Table 6. Explanation of the number of foreign subsidiaries

\begin{tabular}{lcc}
\hline Variables & Regression coefficient & Prob > F \\
\hline Population & 0.00001 & 0.0001 \\
Number of international congresses & 0.10221 & 0.0001 \\
International population potential & 2.06127 & 0.0044 \\
International airflows & 0.0002 & 0.0127 \\
$R^{2}=0.763$ & & \\
\hline
\end{tabular}

es (Table 6). The size of cities is combined with their number of congresses, their international population potential, and their attractivity for air traffic.

The selection of the variables shows that it is not only the general accessibility but also the specific location which is of importance, ince the number of foreign firms per inhabisince the number in cities not too far from a the advantage of increasing the simultaneous accessibility to various national markets. This effect is especially high in the smallest counefrect is espy partly explain, together with the tries. It may party explain, smaller size of the national market, that the level of penetration of their urban economy by foreign investments is always higher than in the largest countries.

The interpretation of the accessibility factor is reinforced by a positive correlation with the availability of high-level accommodation in international hotels (Figure 8). The more accessible the cities are, the more likely it is that they will receive subsidiaries within the internationalisation process. It is interest ing to note that the number of international congresses, which is another indication of the internation, attractivity of cities, has the internationation pattern (Figure 9).

However, it is interesting that there is no

However, it is interesting that there is no relationship between the attractiveness of cities for foreign firms and their own dynamism as measured by the growth rate of their population. Structural differentiation within the European urban system seems then to be of Eureper urban system seens then to be of greater importance internationalisation process.

for the internationalisation process.

When the number of firms is measure erion factors the international airflows. are revealed for the headquarters, on the one ind for the subsidiaries on the other he quarters per inhabitant is still correlated with city size, as well as the number of foreign firms that they control. However, that last correlation depicts only the extreme situation of London and Paris and does not exist for the lower levels of the urban exist for the lower levels of a result also suggests that he attractivity of city size on headquarters location is not a simple mass effect bu that it has a quali-tative dimension whic consists of the proximity to economic and politic decision powers in the larges European capitals.

The location of subsidiaries in cities is The location of subsigtaries in cities is mainly a matter of geographical situation (Figure 8). The accessibility level is the most important factor, as measured for instance by

\section{Conclusion}

More research of comparable indices Mre fore concluding about the factors leading the strategies of foreign firms when they choose a European city for developing their activity. In particular, more detailed comparable information about the economic profiles of cities is needed to investigate the links between urban functions and the internationlisation process. However, the main trend is clear: for their internationalisation, firms tend to privilege the largest cities. This effect is strongest for the location of headquarter and for financial branches. It accompanies the process of metropolisation in the urban system, which reinforces, at least at present,

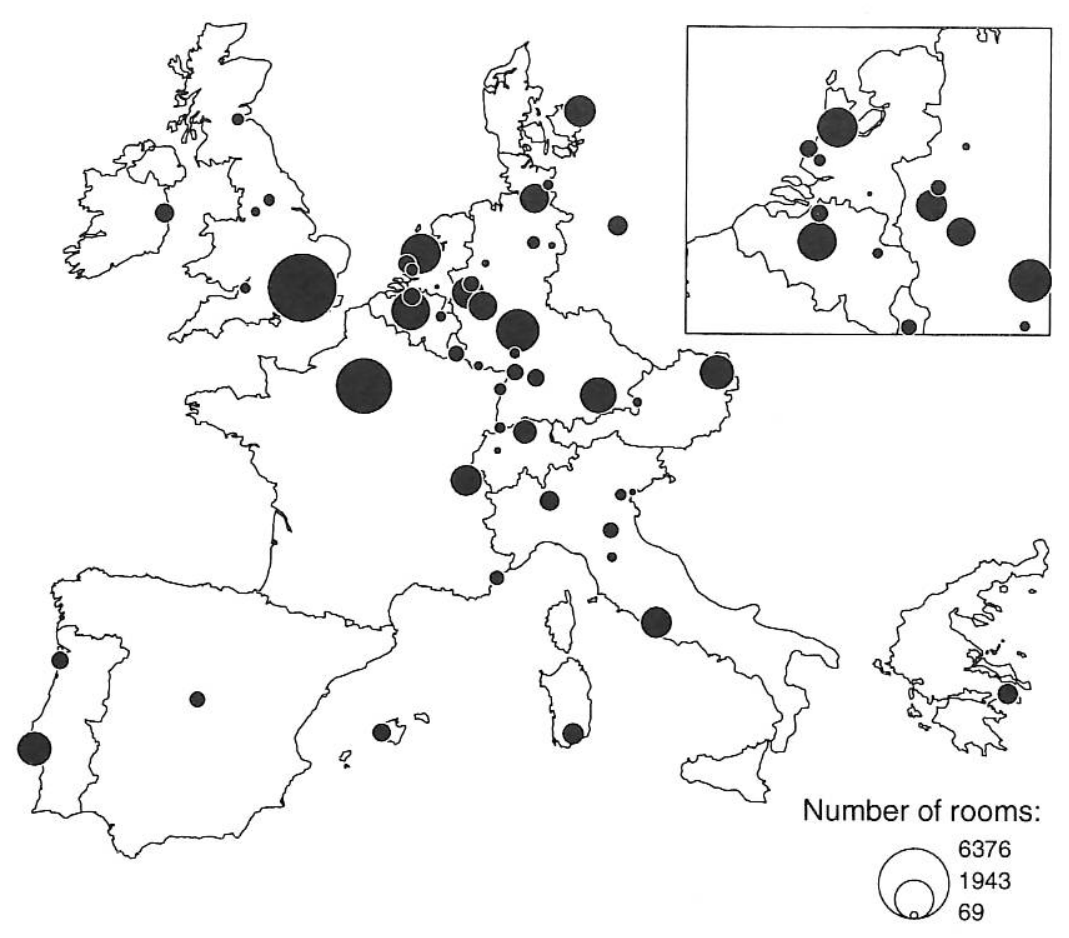

Figure 8. The location of international hotels. Source: International Hotels Association (1990).

the top of the urban hierarchies through the internationalisation of all kind of exchanges and communications.

Without any intervention, it is highly probable that the European urban system is entering a period of concentration of, if not so much population, at least of skill and activities in its largest centres. The trend to 'counter-urbanisation' has not been so important in Europe as in the US; it has been mainly a process of local deconcentration of the population in the most densely populated areas, without any strong revitalisation of smaller towns or strong decline of the largest urban centres-except perhaps in the UK. The end of the 1980s and the first results of the 1990 censuses show on the contrary, together with a continuing local deconcentration of the densely populated areas, a new trend in concentration of population in the largest cities (Pumain and Faur, 1991). This will increase territorial imbalances, since almost 50 per cent of the population already lives in the approximately 400 cities of over
100000 inhabitants, on less than 5 per cent of the surface.

However, the role of multinational firms in the process of the internationalisation of the European urban system may not be limited to the metropolisation process. The firms which have the longest history in the internationaliation process locate themselves in smaller centres 'technopoles', or tourism, already show slight preferences for small or medium-sized cities. Counterbalancing policies could trade upon those differential propensities to aggregate in metropolises. They could also compensate for the main advantage of the largest cities, which is the universality of their image outside their country, by diffusing knowledge about the real comparative advantages of other cities. Better information should also be given about the social and physical environments, recognising the indispensable variety of an urban system in complex societies. Policies also may act by 


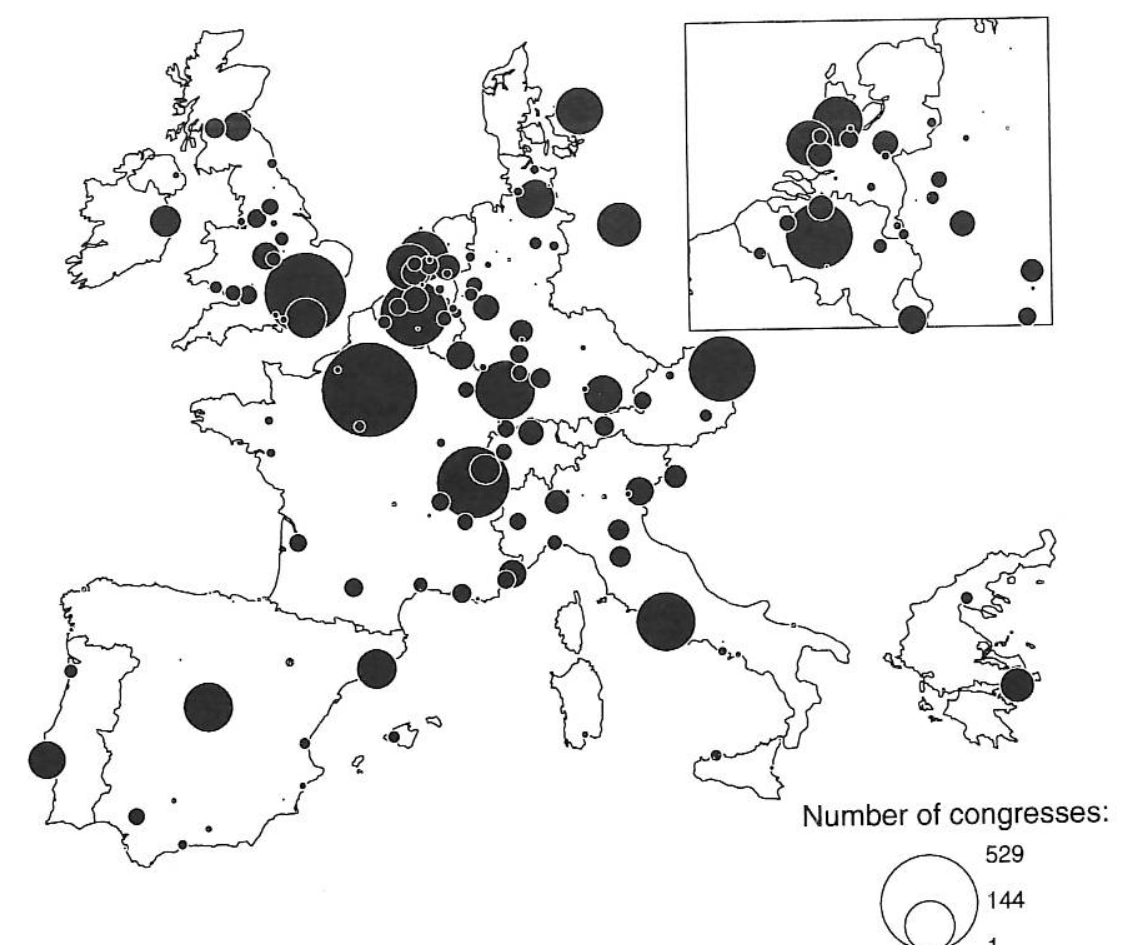

Figure 9. The location of congresses, 1987-90, in cities having more than 200000 inhabitants. Source: International Congress Calendar.

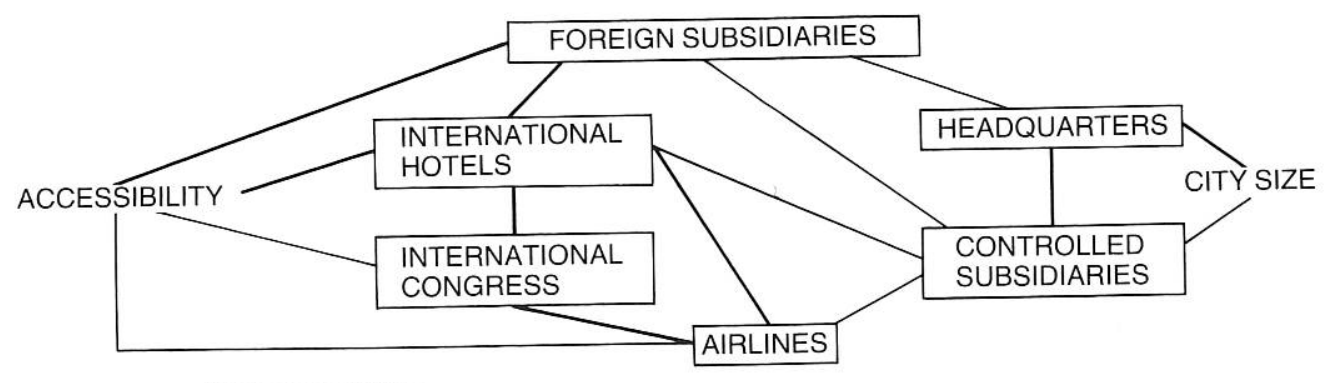

- Strong correlation

(All indicators are measured per inhabitant)

Figure 10. Multinational firms and other international functions.

spreading out the infrastructures for communication and transport, which are the second location factor by importance. Due to the cost of large infrastructures, this is however not the actual trend.

\section{References}

AUPHAN, E. (1991) Quel avenir pour les réseaux ferres d Europe occidentale. Memoires et Doc-

YDALOT, P. (1985) Economie régionale et urbaine. Paris: Economica.
BIEBER, A. (1990) Influence de la grande vitesse ur la restructuration de l'espace européen UTHen. P. Busson, MA Commercon, N.

and Rousirr, N. (1991) Villes européenes maternationalisation. Paris: DATAR; Lyon: ADERLY.

BRUNET, R. (1989) Les villes "européennes". Paris: RECLUS-DATAR, La Documentation française

CATTAN, N. (1990) Une image du réseau des villes europeennes par le trafic aérien, L'Espace Géographie, 2, pp. 105-116.

CATTAN, N. (1991) The network of large cities and inter-urban flows. Paper presented at the Seventh European Colloquium on Theoretical and Quantitative Geography, Stockholm.

CATTAN, N. and ROZENBLAT, C. (1991) La comparaison des villes européennes, Population,

Cauvin, C., Reymond, H. and Schaub, G. (1989) Accessibilité, temps de séjour et hiérarchie urd'Europe occidentale, Sistemi Urbani, 3 , pp. 297-323. London.

EC (1990) Europe 2000: Outlook for the Development of the Community's Territory. Doc. COM90 544. Luxembourg: Communication from the Commission to the Council of the European Parliament.

Hall, P. and HaY, D. (1980) Growth Centres in the European Urban System. London: Heine-

FO (1990) An empirical assessment of factors shaping regional competitiveness in problem Wirtshaftsforschung, Brussels.

WTERNATIONAL HOTES AsSOCIATION (1990) Yearbook. Paris.

M.O.C.I. (1989) Les villes françaises à l'international, 895, pp. 17-24.

MORICONI, F. (1991) Les 100 plus grandes villes du monde, Economique et Statistique, 245, pp. 7-19.

MORICONI, F. (1993) L'urbanisation du monde depuis 1950. Paris: Anthropos.

RED, A. (1977) City Systems in Advanced Economies. London: Hutchinson.

PUMAIN, D. and FAUR, J.P. (1991) Villes et région au rendez-vous de l'Europe, Population el Societe, 257.

Sumain, D., Saint-Julien, T., Cattan, N and ROZENBLAT, C. (1990) Le concept statisEUROSTAT

La localisation des siège en Europe occidentale, Travaux de Institut de Géographie de Reims, 31-32, pp.

19ZENBLAT, C. (1991) Les entreprises étrangères dans les villes francaises, Annales de Géogra-

(DENBLAT, C. (1992) Le réseau des entreprises multinationales dans le réseau des villes Pe doctorat, Université de Paris I. 